

\title{
Spacing Commemorative-related Violence in Northern Ireland: Assessing the implications for a society in transition
}

McDowell, S., Braniff, M., \& Murphy, J. (2015). Spacing Commemorative-related Violence in Northern Ireland: Assessing the implications for a society in transition. Space and Polity, 19(3), 231-243.

https://doi.org/10.1080/13562576.2015.1057372

Published in:

Space and Polity

Document Version:

Peer reviewed version

Queen's University Belfast - Research Portal:

Link to publication record in Queen's University Belfast Research Portal

Publisher rights

(C) 2015 Taylor \& Francis

This is an Accepted Manuscript of an article published by Taylor \& Francis in Space and Polity on 03/07/2015, available online: http://wwww.tandfonline.com/10.1080/13562576.2015.1057372.

\section{General rights}

Copyright for the publications made accessible via the Queen's University Belfast Research Portal is retained by the author(s) and / or other copyright owners and it is a condition of accessing these publications that users recognise and abide by the legal requirements associated with these rights.

Take down policy

The Research Portal is Queen's institutional repository that provides access to Queen's research output. Every effort has been made to ensure that content in the Research Portal does not infringe any person's rights, or applicable UK laws. If you discover content in the Research Portal that you believe breaches copyright or violates any law, please contact openaccess@qub.ac.uk. 


\title{
Spacing Commemorative-related Violence in Northern Ireland: Assessing the implications for a society in transition
}

\begin{abstract}
This paper explores the geography of commemorative-related violence in Northern Ireland and considers its ramifications for a society in transition. Using original primary research, this article contributes to discussions on violence, space and memory through a spatial analysis of new quantitative archival data and existing archival material explored through a multi-disciplinary lens. It examines the complex relationship between the practices and processes of commemoration, the violence that it sometimes occasions and the places in which such violence exists. In unpacking this specific form of violence we consider the continued importance of both place and past in a post-conflict society. This includes a concern for the changing structures and forms of governance that influence how the past is negotiated as Northern Ireland marks a decade of commemorations leading up to the centenary of its contested creation.
\end{abstract}

Key words: space, commemoration, violence, conflict, memory, Northern Ireland 


\section{Introduction}

On June 27th 2012, the Deputy First Minister of Northern Ireland and former IRA commander, Martin McGuinness shook hands with Queen Elizabeth II for the first time at an event in the Lyric Theatre in Belfast. For many the gesture symbolised the consolidation of Northern Ireland's transition to peace, the meeting of disparate cultures and traditions, and renewed hope for the future. However, only a few weeks later violence spilled onto the streets of north and west Belfast following conflict over a series of commemorative parades, marking a summer of hostilities. Those hostilities spread into a winter of protest, riot and discontent surrounding the intractable issues of flags and emblems. Outwardly these examples present two very different pictures of the 'new' Northern Ireland; the former of a society moving forward and putting the past behind it and the latter both divided over and wedded to the past. Furthermore they revealed two very different 'places', the public handshake in the arena of public space; the rioting and fighting occurring in spaces distanced from the public sphere. The existence of these dual places in post-conflict Northern Ireland is well-documented (Neill 1995, 2006; Shirlow and Murtagh 2006; Switzer and McDowell 2011; Nagle 2012). Murtagh (2006), for example, has referred to Belfast as a 'twin speed city' with different parts of the city moving at considerably different paces. Belfast, serving as a microcosm for Northern Ireland, is a city in transition and as such is a site of dichotomies; a place of peace and violence; a place of prosperity and deprivation; a place of remembering and forgetting. In a post-conflict society of such dualities, the violent outworking of continued division is not unprecedented. Peacetime violence in all its forms: sectarian, political, racist, informal, domestic and ‘everyday' in Northern Ireland remains a formidable challenge (McAlister et al, 2013; Feldman 1991; Muldoon 2004).

This article significantly contributes to the study of violence, space and memory by seeking to map and unpack forms of violence that can sometimes surround efforts to bring the past into focus in the present and situates this violence within the context of post-conflict transition and tension. The phenomenon of what we term 'commemorative-related violence' has been a persistent problem in the post-accord years, ebbing and flowing in specific places and highly attuned to changes in the political landscape. Commemoration in Northern Ireland is multi-faceted and embodies a wide range of activities from parades to the dedication of gardens or windows of remembrance, anniversary gatherings to theatre performances, artworks to literature and includes the unveiling of plaques or murals. The role commemoration and its complex relationship with place in transitional and post-conflict 
societies has been well-documented (see for example Marshall 2006; Johnson 1995; Dwyer 2002). While memory-work has many positive functions in such societies such as assisting in the realisation of transitional justice through enacting a form of symbolic reparation (Hamber 2004); fostering pathways to forgiveness and reconciliation (Brewer 2006); underpinning nation-building (Marschall 2008), and reaffirming and consolidating place attachment (Raento 2006); it also has the ability on occasion to act almost as a war by other means in the present, exacerbating and perpetuating conflict on a symbolic level (McDowell and Braniff 2014; McGrattan 2012). In Northern Ireland, the practices and processes of memory and commemoration have been acutely important to many throughout the peace process; employed in battles for power and space; to contest the validity and legitimacy of the 'other', in debates over claims to hegemonic victimhood; to give credence for campaigns for social justice; to acknowledge loss, grief and sacrifice; to bolster and sustain identity; to redress conflict and to mediate the path to peace. However, it is important to pause and ask 'why do some of these activities trigger violence?' And if they do, is the commemoration simply a guise masking deeper-rooted issues? Is it contestation over the past that instigates violence or is it rather the dynamics or specific characteristics of the place in which the violence occurs that serves to exacerbate tension and emerge as violence? In thinking about and conceptualising this violence, this article has two key objectives. The first is to question why the performance or celebration of the past through memorialisation, anniversary gatherings, parades and rituals can sometimes lead to violence in specific places and to identify any specific themes or trends by spatially analysing the manifestation of violence throughout Northern Ireland. The second objective is to explore the implications of this violence as the region continues to consolidate its transition to some form of peaceful future despite the advent of potentially contentious anniversaries.

Research approach: Conceptualising violence, place and past

There is of course an inherent complexity in attempting to conceptualise firstly the nature of violence in a post-conflict society and secondly what triggers forms of collective violence. Steenkamp's (2007) seminal work is a useful starting point for thinking about the legacy of violence and its pervasive nature following armed conflict. She suggests that the use of violence within transitional or post-conflict societies can often be attributed in part to protracted violence and its conditioning effect on specific communities within society. The 
term a 'culture of violence' is often used to describe societies where violence continues to feature in a post-conflict context. Through protracted conflict, violence becomes enmeshed and intertwined with the 'broader shared, values and norms of a community' (Steenkamp 2007, 13). Violence in such situations transcends its original function as a political act and is employed to deal with issues that would not ordinarily occasion conflict in a 'normal or peaceful society'. Steenkamp notes that it can become 'trivialised and every day, and a socially acceptable mechanism to achieve power and status in society' $(2007,13)$.

Furthermore the use of violence is not clearly uniform and differs across and between communities (and as we argue in this paper between specific places). Steenkamp's framework identifies four levels where violence can occur: the international, the state, the collective and the individual, all of which can be interlinked. The individual, she suggests, can become predisposed to use violence through long-term exposure to it. Individuals can also use violence to articulate feelings of exclusion and disempowerment. There is clear evidence to suggest that these existential issues inform and lend to both individual and collective forms of violence in Northern Ireland. Under this framework commemoration can be read as a catalyst for deeper, structural issues that are embedded within society. Jarman's (2004) discussion of violence in Northern Ireland between 1994 and 2002 points to a string of variables which occasion violence including disputes over parading, the continuing presence of paramilitary organisations and the marginalisation of young people.

This research extends this debate and situates this conceptualisation of a culture of violence within a reading of place. Do the broader structural issues identified by Steenkamp (2007) exist in specific places? And are there particular circumstances, environments and places makes the eruption of violence more probable? Place is fundamentally important in Northern Ireland. Identities remain acutely territorial. Boundaries, both visible and invisible have marked the Northern Irish state since its inception in 1921 (Arthur 2000, 35). Boundaries, as Sibley (2001) suggests, reflect concerns about difference. The construction of physical boundaries in the 1960s and early 1970s in Belfast, for example, was triggered by a period of intense inter-communal violence resulting in an exodus of refugees into the 'sanctuaries' of ethnic enclaves. Residential segregation 'sharpened' (Boal 1982), with each outburst of conflict. This segregation 'ratchet' quickly became permanent. Significantly, residential segregation did not curb or minimise violence as intended; instead, it had the adverse effect of reproducing and mobilising it. Indeed, the perpetrators of violence sought out potential victims within such enclaves where they would be sure of killing someone of a 
certain religion (Peach 1996, 144). Fear of the 'other' had an overwhelming impact on the psyche of each enclave's inhabitants. Residents developed 'codes' or cognitive 'maps' which, determined safe or dangerous spaces which in turn restricted and defined mobility (Shirlow 2001; Sibley 1995). Bound together by ethnicity and fear, the geographical splintering of Northern Ireland's population produced single-identity communities exhibiting strong levels of social capital and tightly-knit bonds (Sennett 1970). Both Loyalist and Republican paramilitaries contributed greatly to restricting mobility and integration between the 'two' communities and helped create spaces of fear through and exercising the means to punish, control and define inclusion or exclusion within their respective territories (Zurawski 2005, 507). Violence, and fear of violence, has been and continues to be a constant feature of daily life within some of these communities despite the onset of peace. Within such areas, remembering past attacks upon the community is paramount to the ongoing sense of fear and division. The past and its negotiation in the present through the practices and processes of commemoration which are manifested in physical and public spaces is then a key feature of establishing control and reproducing division within specific communities and the places they reside in. Memorialisation plays a dynamic role in claiming space and is just as much a producer of boundaries as a product. In Northern Ireland the past is a point of contention and is continually reappraised, memorialised and transmitted. It has periodically descended into violence despite legislative and community frameworks to minimise this occurring.

Gladwell's (2003) drawing together of system research around tipping points and emergent social phenomenon also finds resonance in explorations of violence. He suggests that the dynamics of any particular process can change suddenly at a particular point, with three the presence of three common characteristics: contagiousness, small causes having big effects; and the fact that change occurs dramatically, not gradually. In turn, Stieglar (2013) thinking specifically about outbreaks of violence, suggests that citizens within capitalist societies are increasingly disaffected and uncontrollable making their responses to systems of law and governance unpredictable and volatile. Moser and Horn (2011) identify an urban tipping point when violence erupts and becomes generalised. Such violence typically takes place under highly charged political or economic circumstances and is often triggered by responses to or the management of such circumstances. The presence of external or environmental factors can also contribute to the likelihood of violence. Things as banal as the weather, the particular time of the day and the presence or lack of alcohol for example can often influenced the course of collective outbreaks of violence (Cohn 1990). 
Post-conflict violence in all its guises presents policymakers and public bodies with a specific set of challenges. The policing and security cost of violent dispute surrounding the celebration and commemoration of specific historic events in Northern Ireland was $£ 7.4$ million in 2012, which included $£ 6.1$ million for policing commemorative parades and subsequent disturbances in the 5 months between April and August (Northern Ireland Policing Board 2012). In 2013 this figure was even higher at $£ 15$ million between 1 April and 31 July with the majority being spent on the 21 days around the Twelfth (Northern Ireland Policing Board 2013). The wider macroeconomic costs, including lost tourism revenue, and reduction in potential inward investment are much more difficult to ascertain. However the ramifications of such violence reverberate far beyond economics, affecting the physical and psychological wellbeing of those who are exposed to it. Since the inception of the peace process in Northern Ireland, commemorative-related violence has arguably dented efforts at building peace, at a local level by damaging inter-communal relationships in specific communities, and regionally through the triggering of crises within the devolved government. Across the spectrum of political governance, the spatial spread of commemorative-related violence has created challenges for the newly constituted police service as well as those bodies challenged with devising and implementing strategies for commemorative activities such as the Parades Commission (Murphy, 2013). Since the signing of the 1998 Agreement, commemorative-related violence has further exacerbated existing tensions between the police who are tasked with responding to violence and the communities whose neighbourhoods it occurs in (Belfast Telegraph 14 December 1998). The future is also a concern. Acute levels of violence in 2012 were especially worrying given that Northern Ireland had just embarked upon a series of potentially controversial anniversaries leading up to the centenary of its birth in 2021. Commemorative-related violence raises important questions about a society in transition and how it is moving forward, dealing with the past and planning for the future. These issues are at the crux of debates surrounding the future of sharing space and developing robust structures of governance in Northern Ireland.

In seeking to unpack the very complex relationship between commemorative practices and violence in Northern Ireland, this research article identifies where violence of this nature occurs and attempts to unpack some of the reasons as to why it occurs in particular places. In mapping where violence occurs we can begin to investigate the characteristics of place, unravelling its many layers and exploring its connections to the past. The data presented in this approach was collated using a triangulated research methodology which 
comprised quantitative and qualitative approaches. In locating the places where commemorative-related violence has taken place the research incorporated Police Service of Northern Ireland (PSNI) statistics and media accounts of violence. In further understanding the characteristics of the places where violence has occurred we analysed data from both the Northern Ireland Census and the Northern Ireland Neighbourhood Statistics Information Service. A dataset of commemorative-related violence documenting incidents between the signing of the Belfast/Good Friday Agreement in 1998 and the end of 2012 was subsequently produced. A range of commemorative practices were considered such as the unveiling of commemorative monuments, memorials, murals and other art forms, the practice of commemorative parading; anniversary gatherings and commemorative bonfires. These practices and processes acknowledge and remember not only Northern Ireland's recent past (locally known as the Troubles) but it's more distant including the commemoration of the 1689 Battle of the Boyne, the 1798 Rebellion, the Easter Rising 1916, The Battle of the Somme and the War of Independence 1922. This data was then incorporated into a Geographic Information System (GIS) which spatially mapped violent incidents and permitted the layering of a range of additional data (such as deprivation indices, religious composition of neighbourhoods-community background and physical interfaces between segregated communities in Northern Ireland) to explore and analyse the specificity of place and the influence of 'place' on commemoration and violence. In contextualising this violence we conducted a series of semi-structured interviews with a number of diverse actors including political parties, the PSNI, community organisations and cultural groups.

Analysing the data: Triggering commemorative-related violence

Since, the 1998 Good Friday/Belfast Agreement commemoration in Northern Ireland occurs in both private and public space but what happens in public space (and in specific public places) appears to be much more likely to lead to some form of violence. It should be noted primarily that the practices and processes of memory and commemoration are overwhelmingly nonviolent and do not tend to occasion or result in violence of any form. That is not to suggest that they are not conflictual or contested; there is a plethora of work that points to the capacity of commemoration to invoke division or exacerbate strained relationships (Jarman 2001; McDowell 2012) facilitating a war by other means or a symbolic conflict (McDowell and Braniff 2014). Equally, there are many more examples of commemorations that did instigate 
outbreaks of violence. In the years between 1998 and 2012 we documented 384 violent incidents/episodes across Northern Ireland (see Figure 1). This ranged from large-scale rioting that spanned days or weeks and involved scores and even hundreds of people to attacks on individuals or properties in the run up to or aftermath of some form of commemorative act. Our data suggests that anger or contestation resulting in physical violence following a commemoration or the way that commemoration was managed by the organisers and participants, or even responded to by the public bodies including the PSNI, can have a knockon effect across and within communities and their respective geographies; in some incidences there is evidence to suggest that violence is a response to a commemoration that has no direct association or connection with the space in which the violence occurs. It is also important to recognise that violence often attributed to the performance of memory in a particular space can originate from other deep-rooted tensions within a community-from those structural issues that Steenkamp (2007) refers to in her work. In such instances commemoration ignites a flame that has its origins elsewhere: from within the disempowerment and marginalisation felt within communities or from paramilitaries engaged in tribal warfare with a divergent faction. In other situations it speaks to claims that there is a lack of respect for specific cultures and traditions.

A central finding from this research was that certain types of commemorative practices are more likely to result in violence than others. In a study of the unveiling or construction of over 500 monument/memorials/murals during the peace process years, we found that less than $1 \%$ instigated any form of violence. Commemorative parades, perhaps unsurprisingly, are much more likely to trigger violence than any other form of commemoration, which supports existing studies in the field. The tradition of parading is well established in Northern Ireland and predates the region's contested inception, dating back to the early 1800s when across the island of Ireland communities processed through villages and towns to commemorate and celebrate their heritage. Parades by their very nature are powerful if ephemeral spatial practices, which articulate the relative capacity of a given community to express power and identity through ritual and performance (Marlston 2004). In Northern Ireland they have become a cornerstone of both Unionist and Nationalist identity employed largely by the former to bring the past into focus in the present (see Jarman and Byran 1998; Dunn 2000; Fraser 2000; Bryan 2000). Of the most celebrated, and most contentious, is the Twelfth of July celebrations organised by the Orange Order, which takes place annually to commemorate the victory of King William of Orange at the Battle of the Boyne in 1690Of course, the Orange Order parading tradition forms only a percentage of all parades (Bryan 2000: 99-102). Of the 2687 
loyalist parades in 2013 for example, 52\% were Orange Order, 7\% were Apprentice Boys, 17\% Royal Black Perceptory and a range of other loyalist organisations comprised the remaining 24\% (Nolan 2014). This comprised 61.8\% of the total parades for that period. Whereas, nationalist parades comprised 3.2\% of the total and the remainder were civic or cultural events. It should also be noted that there are more than 4000 parades throughout Northern Ireland annually and most of these proceed without violence (Parades Commission 2014). Drawing upon PSNI statistics, Nolan (2014: 159) confirms that within the parading season, most costs are expended policing loyalist parades that subsumed $£ 17,688,805$ of duty time and over $£ 4$ million additional costs which include police-time dedicated to policing public disorder as well as damage to policing vehicles.

Spaces of commemorative-related violence

The mapping of commemorative-related violence across Northern Ireland reveals a considerable urban-rural divide with urban spaces, namely cities, much more likely to experience commemorative-related violence than rural spaces. This correlates with what we already know about violence in divided or conflictual societies more generally and strikes a chord with Northern Ireland's experience of sectarian and ethno-nationalist violence during the Troubles. Cities like Belfast and Derry for example registered the highest levels of violent incidents throughout the Troubles (Fay et al, 1999). Our research found that between 1998 and 2012 these cities also registered the highest volumes of commemorative-related violence. Again, like the Troubles the phenomenon of violence is located in specific spaces within these urban places and do not sporadically occur in a range of diverse parts. . The relationship between space and its historical as well as contemporary experience of violence facilitates a more in depth understanding of how people engage with the narratives of a site and space, as well as its communal and inter-communal experience of conflict and division.

Of significance is the number of spaces which witnessed a dramatic decline in violence throughout our study period. The city of Derry/Londonderry is perhaps the most obvious example. Disputes surrounding parades had been omnipresent throughout the latter years of the Troubles and most acute in the late 1990s only to be transformed throughout the postAgreement years. Some of the most intense violence occurred during the annual Apprentice Boys march when Loyal Orange Parade walked along the reopened city walls, one section of which looked down onto the nationalist community of the Bogside where violence throughout 
the Troubles had been particularly acute during the late 1960s and early 1970s. Residents accused the parades of being inflammatory and sectarian and argued that to march past their area was in direct opposition of their human rights. Rioting and intense violence followed each of the parades. Yet the Protestant community in the city of Derry/Londonderry has been experiencing their own feelings of disaffection and what Cohen (2007) terms spatial dissonance. With a dwindling Protestant population on the West Bank of the City, the last Protestant enclave of the Fountain remained a bastion of a claim on the city that stretched back to its plantation in 1689.

Declining levels of violence in Derry have been attributed in part to increasing dialogue between community actors and a shift in the stewarding of parades in the city (Bryan and Jarman 2000). Despite violence in the city in the winter of 1998 over commemorative parades, the events of the following summer signalled the possibility of some kind of transition. The annual Royal Black Perceptory parades did not oppose the Parade’s Commission’s decisions to restrict or alter its route. While restrictions were placed on similar parades across the County of Londonderry, the Royal Black Perceptory parade was not opposed by the local Bogside Resident's Group, and this hinted that further parades in the City had the potential to be less contentious (Belfast Telegraph 24 August 1999). While the potential for parades to trigger violence lessened significantly it not completely subside in the immediate years following the signing of the Agreement. There continued to be smaller scale and sporadic episodes normally triggered by the $12^{\text {th }}$ July parades and typically located a interfaces with a strong association with violence in the past. For example, in July 2001, violence took place across urban spaces in Northern Ireland including parts of Derry City at interface areas between Nationalist and Unionist communities (Gobnascale/Irish Street Bogside/Fountain Estate) (Belfast Telegraph 13 July 2001).

Many spaces that bore much of the violence throughout the Troubles continued to experience violence and contention throughout the early post-agreement years, yet with vastly reduced levels of violence. Like specific areas in Derry City, the Lower Ormeau Road in Belfast was one of a number of flashpoints in Belfast where contention over parading, significant policing and protesting culminated in violence for a number of years. Ardoyne, the Crumlin Road and the Short Strand/Newtownards interface experienced similar (at times much worse) levels of violence post-agreement. The Ormeau Road/Ballynafeigh dispute alleviated due to local community talks, the rulings of the Parades Commission and continued local engagement. 1998 marked change in the nationalist opposition to parades in the area following 
the death of the three young brothers in a sectarian attack in Ballymoney following heightened community tensions surrounding commemoration in that area 30 miles north of Belfast. This typifies social bonds ‘within’ communities and calls to mind Renan's notion of ‘suffering in common unifies more than joy does' the social and cultural bonds were strengthened within nationalists and unionists by their perceived oppression over commemorative parades. This calls to mind Anderson's imagined communities where the perceived kinships and the imagined 'communion' within each community across Northern Ireland become easily reified through the cultural and emotive practices and protests around parading (1991: 5).

Following the signing of the 1998 Agreement, the location of much of the commemorative-related violence took place in Portadown, Co. Armagh and this site triggered discord, instability and violence elsewhere in Northern Ireland including Derry City where rioting extended into mid-December (Belfast Telegraph 14 December 1998). Again, the ‘duality of space’ was notable as Derry’s John Hume received the Nobel Peace Prize just fortyeight hours before that incident of commemorative-related violence following an Apprentice Boys parade in the City. While incidents of violence took place across Northern Ireland the heart of the instability lay at one corner of mid-Ulster, Portadown. Lurgan and Craigavon came to represent a mid-Ulster 'murder-triangle' which experienced high levels of violence and Troubles' related deaths beyond the cityscapes of Derry City and Belfast. Predating and outlasting the 1998 agreement, the dispute at Drumcree in Portadown reveals much of the temporal and spatial nature of commemorative-related violence in Northern Ireland.

The dispute over the right to parade at Drumcree a contentious interface area in Portadown in the summer of 1998, triggered widespread incidences of sectarian and intercommunal violence including the burning of Catholic chapels, roadblocks and disruption to public transport. In addition to the 384 violent incidents and episodes in the period that were directly linked to commemorative activities during the fourteen years post-Agreement, the wider context of violence surrounding the discord over the Drumcree dispute is notable. For example there were 509 petrol-bombing incidents with 1,687 petrol bombs recovered and 154 hijackings took place across Northern Ireland (Belfast Telegraph 2 July 1998). The death of three brothers in a fire-bomb attack on their home in Co Antrim on the $12^{\text {th }}$ July marked the tensions in Northern Ireland in 1998 and was soon followed by the Real IRA bombing in Omagh town centre which killed 29 people. Far from relegating violence to pre-agreement life, one of the most notable trends is that there appears to be emerging spaces of violence. Essentially, these are places which historically did not experience violence and/or public 
disorder during the conflict but are now witnessing violence as a consequence of commemorative events. Whether or not these commemorations are 'new' in the sense that they have not been actively remembered in that particular space is difficult to ascertain but the memory and/or the space has obviously acquired a new significance in a post-conflict context.

Deprivation and commemoration

Linked to the wider policy areas of managing and responding to the direct and immediate impacts of commemorative-related violence, our study revealed an important relationship between commemorative-related violence and deprived communities. Relative deprivation is described as the discrepancy between an individual's perceptions of their value against their capability. Relative Deprivation theory traditionally been employed to explain the genesis of social protest (Dubé and Guimond 1986), although it concentrates on the individual in order to describe and explain collective discontent. The kind of discontent that leads to violence has been subject to widespread debate. Gurr's (1970) seminal work suggests that the primary source of the human capacity for violence is the frustration-aggression mechanism where increased levels of disaffection can make aggression and even violence more probable. This analysis is not without its problems; more recently psychologists have pointed to the structural and organisational influences that impact the likelihood of violence. One of the key objectives of our study was to examine whether or not deprivation indicators influenced outbreaks of violence in Northern Ireland, if at all. A significant finding of the study was that there the highly significant relationship between commemorative-related violence and levels of deprivation. Our findings revealed that $48 \%$ of commemorative-related violent incidents between 1998 and 2012 occurred in the top 10\% of the most socially and economically deprived electoral wards in Northern Ireland.

For instance within Belfast there is a strong relationship between the incidents of commemorative-related violence recorded against the Multiple Deprivation Measures (MDM) rank of the Super Output Areas they occurred in. The key findings of this research were concerned not only with identity and space, but also how this reflects deprivation statistics and demonstrated that the relationship between high deprivation, commemorative events and violence was convincing. Furthermore, the challenges posed by commemorative-related violence on those communities enduring multiple levels of deprivation is profound, as it has tended to be the case that those communities are historically most affected by Trouble's related 
violence as well as intergenerational poverty. In 2012 for example, rioting and disorder took place following the launch of the Henry Joy McCracken memorial in an area with a MDM measurement of 22 - one of the highest areas of deprivation in Northern Ireland. The area concerned is in Belfast's Shaftesbury ward, which has a Protestant population of (47.3\%). This was a new and emerging space of commemorative-related violence suggesting context specific rather than embedded tensions. The hardline Republican Network for Unity (RNU) were the parade organisers to commemorate Henry Joy McCracken, founder of the United Irishmen. Having passed through nationalist areas, the parade was opposed by protestors from a mainly loyalist background. Violence was the key response. During this incident of commemorative related violence, 50 police officers were injured, four required hospital treatment, a local nursing home was attacked and homes were damaged (Belfast Telegraph 4 September 2012).

An area that has experienced consistent commemorative-related violence is Ardoyne. From 1998- 2012, Ardoyne has experienced a series of commemorative-related violence incidents, it also is ninth most deprived area in Northern Ireland, with 92.8\% from a Catholic background. For instance, in 2003-2006, Ardoyne experienced commemorative-related violence on $12^{\text {th }}$ July with typical experiences of missiles, homes damaged and police injured. This persisted in 2012 when the Parades Commission set a 4pm curfew on the return leg of the Parade, which resulted in dissatisfaction from the Orange Order and bands and consequently violence ensued with 20 police officers injured (Belfast Telegraph 13 July 2012).

Like its counter-parts elsewhere in the United Kingdom, Northern Ireland fell victim to the recession. However, the recession hit much harder in Northern Ireland than England, Scotland or Wales. A recent report by the Resolution Foundation indicated that the recession was much more pronounced in Northern Ireland with its gross added value per head falling 10\% between 2008-2013 (Nolan 2013), only closely followed by Scotland with a 7.6\% fall. This disparity is mirrored in $26 \%$ of workforce earning less than the living wage in Northern Ireland, in comparison to the UK average of 21\% (KPMG 2013). Yet, the gap between rich and poor in Northern Ireland is of less concern than what is commonly understood as the relationship between the two blocs, Catholic and Protestant, in Nolan's terms, 'horizontal equality' (2014). The gap between deprivation in Protestant and Catholic communities is clear with sixteen of the twenty most deprived wards in Belfast being comprised of mainly Catholic populations (NISRA 2010). In post-agreement life, according to McInnes (et al 2012) Catholics remain relatively worse off: 2012 figures of Protestant poverty rates (all ages) stand at 19\%, while Catholics are at 26\%; 28\% of Protestants were in unpaid work (2010-2012) compared to 
$35 \%$ of Catholics; while a potentially more damning social effect is indicated by the $23 \%$ of the population who live in urban poverty and $24 \%$ in rural poverty in the west of the country where Catholics are more numerous, compared with $17 \%$ in the Protestant dominated east. Therefore, when our study revealed that .The Family Resources Survey, cited by Nolan (2014) revealed some distance between deprivation indicators for Catholics and Protestants. For example, it revealed that $25 \%$ of Protestants in comparison to $60 \%$ of Catholics did not have enough money to keep their home in decent décor. The gap persisted with $24 \%$ of Protestants being unable to keep their home warm enough in comparison to $61 \%$ of Catholics (cited in Nolan 2014). The gap between the rich and poor in Northern Ireland can mean eight years difference in life expectancy (DHSSPSNI 2011). Furthermore, the challenges posed by commemorative-related violence on those communities enduring multiple levels of deprivation is profound, as it has tended to be the case that those communities are historically most affected by Trouble’s related violence as well as intergenerational poverty. The 2012 Poverty and Social Exclusion study confirmed that the connection between conflict experience and poverty was prevailing in the post-agreement period having found that:

Those who have these experiences of [Troubles-related] injury are 1.8 times as likely to have had a spell of unemployment for up to 12 months in the last five years compared to those with no experience (of injuries or killings). The deprivation rate (deprived of 3 or more of 22 items) of those with injury experience is $40 \%$ compared to a rate of $30 \%$ for those with no experience of injury or killings (2014: 2).

Undoubtedly, the link between vulnerability to commemorative-related violence and vulnerability to poverty is pronounced in the post-agreement period in Northern Ireland. The direct effects of continued commemorative-related violence in these spaces serve only to prolong the ill-health and poor wellbeing as well as the socio-economic deprivation of the households (Krug et al 2002; Alderman, Hoddinott and Kinsey 2006).

With $48 \%$ of commemorative-related violence occurring in the top $10 \%$ of most deprived communities in Northern Ireland the linkage between violence and poverty extends and compliments recent research, which has focused on the continued relationship between poverty and conflict. As Muldoon explains 'deep social divisions generally accompany political violence; most areas of conflict are particularly affected by other social ills such as poverty, deprivation, sectarianism, or racism' (2008: 465). More recently, the inevitability of poverty and conflict in a post-agreement society continues unquestioned. In their article on the impact of conflict on children and young people in Northern Ireland, Browne and Dwyer assess 
that the challenges posed by continued connections between conflict and poverty in are profound:

Poverty, like conflict, injures people by subjecting them to a general restriction of their human potential. Many communities across Northern Ireland face the same socioeconomic struggles today, which were experienced before and throughout the conflict (2014:801).

Yet, this article proposes that the reality of a post-conflict context is much more nuanced and less condemned to replicate the received wisdoms that deprivation bears out conflict particularly along sectarian lines. The problem with the identity-based approach to examining deprivation and violence is that it serves not only to defer other pluralist approaches to commemorative-related violence, space and deprivation, but also serves to reproduce analyses based upon sectarian head-counting. What is interesting about the findings of this study on the relationship between of commemorative-related violence and deprivation is that the relationship between poverty and conflict is not as inevitable as existing research illustrates, particularly in relation to commemorative-related violence. The emergence of new spaces enduring commemorative-related violence and dissipation of commemorative-related violence in other spaces that have high levels of deprivation illustrates that temporality and the range of management and relationship activities and interventions seemingly have an effect on the propensity for violence in deprived communities.

\section{Conclusion}

It is perhaps unsurprising that commemoration can engender violence given that it is violence that of some kind that is often being commemorated. It is the dead men of war and gunmen who are often captured in murals, remembered in parades and who often occupy the spaces of memorialisation across various territories (McDowell 2008). This article sought to extend the debates around territoriality and violence in a post-agreement context and makes a significant contribution to how we understand the 'peace' that emerges from agreements. Thus, rather than emerging from conflict, Northern Ireland is living with conflict. As novelist Glenn Patterson (2008) points out, Northern Ireland is a 'place where there was brutal violence used regularly and celebrated' which necessitates not only a critical reflection on how such commemoration is managed but also to general attitudes towards violence and towards those who have been 
involved in violence. The phenomenon of commemorative-related violence and its spatial manifestation raises serious questions for both a post-conflict future. The data here points to a very complex relationship between place and past. Some spatial trends underscore the importance of geography and the specificity of place as being more influential in the triggering of violence perhaps than the memory being evoked. Yet the spatial data scratches the surface and does not answer important questions such as whether there a sense of custodianship over either the past or the place which occasions resistance whenever it is threatened; is there an intergenerational impetus to protect and maintain the memory of the past or is the past relatively unimportant for a new generation and a smokescreen for deeper issues surrounding the place? Or is rioting and violence legitimated through the memory of the event being evoked? Parades emerged as the most likely form of commemoration to evoke violence. The potential for commemorative-related violence is increasing with the doubling of parades in 2013 since 2005 (Nolan 2014). Our findings have shown that parading emerged as a strong determinant for commemorative-related violence, rather than the range of other commemorative-activities. As commemorative parades continue to multiply, the spaces in which they continue, and at times emerge for the first time, are vulnerable to the impacts of violence. While dealing with the past and its physical manifestation in the present remains an elusive aspiration, commemorativerelated violence continues to exert an influence on contemporary dynamics between and within communities as well as presenting challenges for political, policy and security elites.

\section{References}

Anderson, B. (1991). Imagined Communities: Reflections on the Origin and Spread of Nationalism. Revised Edition ed. London and New York: Verso.

Belfast Telegraph, (2001) Clashes Flare at Flashpoints, 13 July.

Belfast Telegraph, (1998), Traders count the cost of riot chaos; Derry shops lose (GBP) 1m as violence erupts on streets, 14 December.

Belfast Telegraph, (1999), No Objections by Residents to Blackmen. 24 August.

Belfast Telegraph (1998) Flames of Hate: This is a disgrace, Church blazes outrage, 2 July. 
Boal, F. (1982) Segregation and Mixing: Space and Residence in Belfast' in F. W. Boal and J.H.H Douglas (eds) Integration and Division: Geographical Perspectives on the Northern Irish Problem. London: Academic Press.

Brewer, J. (2006) Memory, truth and victimhood in post-trauma societies. In Delanty, G. and Kumar, K. (eds) The Sage Handbook of Nations and Nationalism London: Sage, pp. 214-224.

Bryan, D. and Jarman, N. (1998) Parading Tradition, Protesting Triumphalism: Utilising Anthropology in Public Policy. In Donnan, H. and McFarlane, G. (eds.) Culture and Policy in Northern Ireland: Anthropology in the Public Arena. Belfast, Institute of Irish Studies.

Bryan, D. (2000) Orange Parades: The politics of ritual, tradition and control, Pluto Press, London.

Cohen S (2007) Winning while losing: The Apprentice Boys of Derry walk their beat. Political Geography, 26(8), 951-967.

Cohn, E G, (1990), Weather and Crime, British Journal of Criminology, 30: 1, pp. 51-64.

Dube., L. \& Guimond, s. (1986). Relative deprivation and social protest: The personal-group issue. In J.M. Olson, C.P. Herman, \& M.P. Zanna (eds.), Relative deprivation and social comparison. The Ontario Symposium, Vol. 4 (pp. 201- 216). Hillsdale NJ: Erlbaum.

Dunn, S. (2000) Bloody Sunday and its Commemorative Parades. In, Fraser, T.G. (ed.) The Irish Parading Tradition: Following the Drum. Basingstoke, Macmillan.

Dwyer, O. (2002) 'Location, politics and the production of civil rights memorial landscapes', Urban Geography, 23, pp. 31-56.

Fay M. Smith M. and Morrissey M. (1999) The Cost of the Troubles. London: Pluto Press.

Feldman, A. (1991) Formations of Violence: The Narrative of the Body and Political Terror in Northern Ireland. University of Chicago Press: Chicago. 
Fraser, T. G. (2000) The Apprentice Boys and Relief of Derry Parades. In Fraser, T.G. (ed.) The Irish Parading Tradition: Following the Drum. Basingstoke, Macmillan.

Gladwell, M. (2003) The Tipping Point: How Little Things can make a Difference. Abacus: New York.

Gurr, T. (1970) Why men rebel. Princeton University Press, Princeton.

Haass, R. (2013) Violence could re-emerge in Northern Ireland, Belfast Newsletter, 12 March, http://www.newsletter.co.uk/news/regional/violence-could-re-emerge-in-northern-irelandwarns-richard-haass-1-5930101.

Jarman, N. and Bryan, D. (2000) Stewarding Crowds and Managing Public Safety:

Developing a Co-ordinated Policy for Northern Ireland. Belfast, Community Development Centre

Jarman, N. (2003) 'From outrage to apathy? The disputes over parades, 1995-2003', The Global Review of Ethnopolitics, 3(1), pp. 92-105.

Jarman, N. (2001) ‘Not an Inch’, Peace Review 13 (1), pp.35-41.

Johnson, N., (1995) ‘Cast in stone: monuments, geography and nationalism’, Environment and Planning D: Society and Space 13 (1), pp. 51-65.

Marschall, S. (2008a) 'Pointing to the dead: victims, martyrs and public memory in South Africa’, South African Historical Journal 60, pp. 103-123.

Marschall, S. (2008b) The heritage of post-colonial societies. In Graham, B. and Howard, P. (eds) The Ashgate research companion to heritage and identity, Aldershot: Ashgate, pp.347364.

Marschall, S., (2006) 'Commemorating 'Struggle Heroes’: Constructing a Genealogy for the New South Africa', International Journal of Heritage Studies 12: 1, pp. 176-193. 
Marshall, S. (2010) 'Commemorating the Trojan Horse Massacre in Cape Town: The Tension between Official and Vernacular Expressions of Memory’. Visual Studies 25 (2): pp. 135-148.

McAlister, S; Haydon, D; and Scraton, P. (2013) Violence in the Lives of Children and Youth in "Post-Conflict” Northern Ireland Children, Youth and Environments 23 (1), pp. 122

McCaffrey, B., (2014) 'The Legacy: Parades, peace talks and the lessons learned', at http://www.thedetail.tv/issues/305/ardoyne-parades-story-for-crc/parades-peace-talks-andthe-lessons-learned, 24 February.

McDowell, S. (2008) 'Commemorating dead men: gendering the past and present in postconflict Northern Ireland', Gender, Place and Culture 14 (4), 335-354.

McDowell, S. and Braniff, M. (2014) Commemoration as Conflict? Memory, Space and Identity in Peace Processes. Palgrave: London.

McGrattan, C. (2012) Memory, Politics and Identity: Haunted by History. Palgrave McMillan, London.

Moser, C. and Horn, P. (2011) 'Understanding the tipping points of urban violence: Conceptual framework’, URBAN TIPPING POINT WORKING PAPER 1, Manchester, University of Manchester.

Muldoon, O. (2004) 'Children of the Troubles: The Impact of Political Violence in Northern Ireland', Journal of Social Issues 6(3), pp. 465-475.

Murphy, J. (2013). Policing for Peace in Northern Ireland: Change, Conflict and Community Confidence, Palgrave Macmillan.

Murtagh, B. and Keavney, K. (2006) 'Policy and conflict transformation in the ethnocratic city’, Space and Polity 10(2), pp. 149-169. 
Muzaini, H. and B.S.A. (2007) Yeoh, Memory-making 'from below': Rescaling remembrance at the Kranji War Memorial and Cemetery, Singapore. Environment and Planning A, 39(6), pp. 1288-1305.

Nagle, J. (2012). 'The Repositioning of Irish Nationalism in Northern Ireland: An Examination of Consocationalism and Devolution in Identity Change'. Ethnopolitics Papers 21, pp. 1-28.

Neill, W.J. (2006) 'Return to the Titanic and Lost in the Maze: The Search for Representation of “Post-conflict” Belfast', Space and Polity 10 (2), pp. 109-120

Nolan, P. (2014) 'Northern Ireland: Peace Monitoring Report', Vol. 3 http://cain.ulst.ac.uk/events/peace/docs/nipmr_2014-03_1-Intro.pdf Accessed 30 August 2014.

Northern Ireland Policing Board (2013) Policing Matters, September 2013, http://www.nipolicingboard.org.uk/final_pdf_-_policing_matters_sept_2013_issue.pdf. Accessed 3 September 2014.

Northern Ireland Policing Board, (2005) Report on the Policing of the Ardoyne Parades $12^{\text {th }}$ July 2005 and the Whiterock Parade $10^{\text {th }}$ September 2005, available at http://www.nipolicingboard.org.uk/sep_parades-2.pdf. Accessed 2 September 2014.

Northern Ireland Policing Board, (2012), Parades Cost Total £7.4 million, available at http://www.nipolicingboard.org.uk/article/?id=1324. Accessed 5 September 2014.

Office of the First and deputy First Minister (OFMDFM) (2013), Together: Building a United http://www.ofmdfmni.gov.uk/together-building-a-united-community-strategy.pdf. Accessed 10 June 2014. 
Parades Commission (2014), Annual Report and Financial Statements, https://www.paradescommission.org/getmedia/c4e4de29-3a2f-4eed-b021985706d4a8a6/NorthernIrelandParadesCommission.aspx. Accessed 20 September 2014.

Patterson, G. (2008) Northern Ireland's veneration of past violence, at Slugger O’Toole, http://sluggerotoole.com/2008/04/09/northern-irelands-veneration-of-past-violence/.

Accessed 10 September 2014.

Peach, C. (1996) The ethnic minority populations of Britain, Vol. 2, Ethnicity in the 1991 Census, Office for National Statistics, Her Majesty’s Service Overseas, London.

Renan, E. (1882) What is a Nation? text of a conference delivered at the Sorbonne on March 11th, 1882, in Ernest Renan, Qu'est-ce qu'une nation?, Paris, Presses-Pocket, 1992. (translated by Ethan Rundell)

Sennett, R. (1970) The Uses of Disorder: Personal Identity and City Life, W. W. Norton and Company, London.

Shirlow P. 2001. 'The geography of fear in Belfast', Peace Review, Vol. 43 12-28.

Shirlow, P. (2003), 'Who Fears to Speak’: Fear, Mobility, and Ethno-sectarianism in the Two ‘Ardoynes’, The Global Review of Ethnopolitics 3 (2), pp. 76-91.

Shirlow, P. (2006) ‘Belfast: The “Post-Conflict” City’, Space and Polity, 10 (2), 99-107

Shirlow, P. and Murtagh, B. (2006) Belfast: Segregation, violence and the city. London: Pluto Press.

Sibley, D. (1995) Geographies of exclusion. Society and difference in the West. Routledge, London.

Sibley D. (2001) 'The binary city’ Urban Studies 38 pp. 38239 - 50.

Stieglar, B. (2013) Uncontrollable Societies of Disaffected Individuals. Polity Press. London. 
Switzer, C. and McDowell, S. (2011) 'Lost spaces: Memory and Forgetting in the Centre of Belfast', Memory Studies, 2 (3), pp. 337-353.

Till, K. (2005) The New Berlin: Memory, Politics, Place, University of Minnesota Press, Minneapolis.

Zurawski, N. (2005) ““I know Where You Live!” - Aspects of Watching, Surveillance and Social Control in a Conflict Zone’, Surveillance and Society, 2 (4), pp. 498 - 512. 